\title{
Short-Term Effect of Sugarcane Straw on Soil Organic Carbon Pools
}

\author{
Luiz Fernando C. Leite ${ }^{1}$, Edvaldo Sagrilo ${ }^{1}$, Ademir Sergio F. de Araújo ${ }^{2} \&$ Henrique Antunes de Souza ${ }^{1}$ \\ ${ }^{1}$ Embrapa Meio-Norte, Teresina, Piauí, Brazil \\ ${ }^{2}$ Universidade Federal do Piauí, Centro de Ciências Agrárias, Teresina, Piauí, Brazil \\ Correspondence: Luiz Fernando C. Leite, Embrapa Meio-Norte, Teresina, Piauí State, Av. Duque de Caxias, 5650, \\ Buenos Aires, 64008-780, Brazil. E-mail: luiz.f.leite@embrapa.br
}

Received: April 20, 2018

doi:10.5539/jas.v10n8p405
Accepted: May 26, $2018 \quad$ Online Published: July 15, 2018

URL: https://doi.org/10.5539/jas.v10n8p405

\begin{abstract}
This study aimed to evaluate the short-term effect of sugarcane straw on soil organic carbon (SOC) stocks in tropical soils. The treatments simulated the maintenance of different rates of sugarcane straw $(0,2.2,5.1,7.8$ and $12 \mathrm{t} \mathrm{ha}^{-1}$ ) applied on the soil surface, with four replication, and evaluated chemical and biological attributes in four depths $(0-0.05 ; 0.05-0.10 ; 0.10-0.20 ; 0.20-0.40 \mathrm{~m})$. Results from soil samples collected in the rainy and dry seasons showed evidence of positive short-term effects of green harvest either on labile and humified soil organic matter (SOM) pools. For the total SOC stocks, we observed linear responses with straw rates in both sampling seasons. A decreased humification index in the topsoil suggests more labile $\mathrm{C}$ pools available in the soil, resulting in a significant increase in microbial activity. Microbial indicators point towards a steady equilibrium in SOC turnover, which can lead to future lower increases in SOC stocks if high straw amounts are maintained on the soil surface. Therefore, long-term studies under low-latitude areas are necessary to model the potential of $\mathrm{C}$ sequestration in sugarcane green harvest systems.
\end{abstract}

Keywords: green sugarcane harvest, soil covering, sugarcane straw, microbial activity, tropical soils

\section{Introduction}

Sugarcane is an important crop in Brazil, mainly due to its close relationship with the renewable energy production sector (Cerri et al., 2009). Currently, Brazil is the largest sugarcane producer, with 734 million tons harvested in 10. 6million hectares in 2016 (IBGE, 2016). Despite its importance for bioenergy production, the management of sugarcane in Brazil includes biomass burning before harvesting, which facilitates the manual harvesting and transportation of sugarcane stalks (Bordonal et al., 2013). On the other hand, this process presents negative environmental impacts, contributing to the increase in atmospheric $\mathrm{CO}_{2}$ concentrations (Cerri et al., 2009) and eliminating the input of sugarcane straw, thus potentially reducing the levels of soil organic matter (Correia \& Aleoni, 2011).

Current estimations show that the majority of sugarcane fields (70\%) in the main producing zones in Brazil have been converted to mechanical harvest, with a significant portion of them $(40 \%)$ being harvested green (Magalhães et al., 2012). Therefore, high amounts of sugarcane straw remain on the soil surface, with values ranging from 13 to $20 \mathrm{t}$ dry mass per hectare (Magalhães et al., 2012). The greater nutrient cycling efficiency of the straw (Souza et al., 2012; Thorburn et al., 2001) is expected to contribute to increased rates of soil organic carbon (SOC) sequestration and reduced use of chemical fertilizers. Previous studies have shown that the input of sugarcane straw increases SOC content over time (Razafimbelo et al., 2006). Razafimbelo et al. (2006) reported increases of $15 \%$ in SOC stocks after six yearsof permanent input of sugarcane straw onto soil, representing an accumulation rate of $0.65 \mathrm{t} \mathrm{C} \mathrm{ha}^{-1} \mathrm{yr}^{-1}$. The variation in SOC accumulation rate depends on climate, soil texture, nitrogen fertilization and the residence time of the straw on the soil surface (Thorburn et al., 2001).

However, the effect of the input of sugarcane straw on soil quality under tropical conditions is unclear. This information could open perspectives toward using the surplus biomass for other purposes such as bioenergy production or alternative bioprocesses for the generation of high-value products (Hernández-Perez et al., 2016). Therefore, the measurement of soil $\mathrm{C}$ and $\mathrm{N}$ stocks as well as soil microbial biomass and activity is important for assessing the impacts of sugarcane straw input on surface soil and the implications for soil quality (Kaschuk et al. 2011). Previous studies have shown increases in SOM and soil microbial biomass through the maintenance of 
sugarcane straw on the soil surface (Razafimbelo et al., 2006; Souza et al., 2012). In southern Brazil, studies have focused mainly on the evaluation of chemical and biological soil processes (Canellas et al., 2007; Correia \& Aleoni, 2011). For low latitude regions such as northeastern Brazil, there is insufficient information about soil properties in the sugarcane cultivation areas. This represents an important gap in our knowledge because sugarcane cultivation in Brazil is rapidly expanding in this region.

The followings were hypothesized: (i) an increase in the rate of sugarcane straw deposited on the soil surface would increase the SOC stocks in their labile and resistant pools; (ii) the increase in labile SOC pools induced by high straw rates would affect the soil microbial biomass and activity positively even at deep soil layers, and; (iii) high addition rates of sugarcane straw would not limit the storage capacity of SOC in the short-term. This study aimed to evaluate the short-term effect of sugarcane straw on SOC stocks in tropical soils.

\section{Materials and Methods}

\subsection{Experimental Area and Treatments}

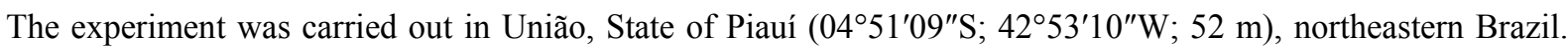
The climate is Aw (Köppen), with dry winters and rainy summers. The mean annual air temperature is $27^{\circ} \mathrm{C}$, with the highest temperatures between September and December. The accumulated rainfall during the experimental period (September 2011 to August 2012) was $1208 \mathrm{~mm}$, with the highest monthly rain amount (317 $\mathrm{mm}$ ) registered in February 2012 (Figure 1). The soil is a sandy Argilluvic Plinthosol (Plinthosol at FAO classification). The chemical and physical properties of soil in the $0-0.40 \mathrm{~m}$ layer are as follows: sand $=787 \mathrm{~g}$ $\mathrm{kg}^{-1}$; silt $=131 \mathrm{~g} \mathrm{~kg}^{-1}$; clay $=82 \mathrm{~g} \mathrm{~kg}^{-1} ;$ bulk density $=1.69 \mathrm{~g} \mathrm{~cm}^{3} ; \mathrm{pH}\left(\mathrm{H}_{2} \mathrm{O}\right)=6.2 ; \mathrm{Ca}^{2+}=1.08 \mathrm{cmol}_{\mathrm{c}^{-1}} \mathrm{~kg}^{-1} \mathrm{Mg}^{2+}$ $=0.59 \mathrm{cmol}_{\mathrm{c}} \mathrm{kg}^{-1} ; \mathrm{Al}^{3+}=0.03 \mathrm{cmol}_{\mathrm{c}} \mathrm{kg}^{-1}\left(\mathrm{KCl} 1 \mathrm{~mol} \mathrm{~L}^{-1}\right) ; \mathrm{K}^{+}=0.3 \mathrm{cmol}_{\mathrm{c}} \mathrm{kg}^{-1} ; \mathrm{P}=37.5 \mathrm{mg} \mathrm{kg}^{-1}$ (Mehlich 1); $\mathrm{H}+\mathrm{Al}=1.59 \mathrm{cmol}_{\mathrm{c}} \mathrm{kg}^{-1} ; \mathrm{SOC}=4.4 \mathrm{~g} \mathrm{~kg}^{-1} ;$ sum of bases $(\mathrm{SB})=2.02 \mathrm{cmol}_{\mathrm{c}} \mathrm{kg}^{-1} ; \mathrm{CEC}=3.60 \mathrm{cmol}_{\mathrm{c}} \mathrm{kg}^{-1}$ and base saturation $=56 \%$.

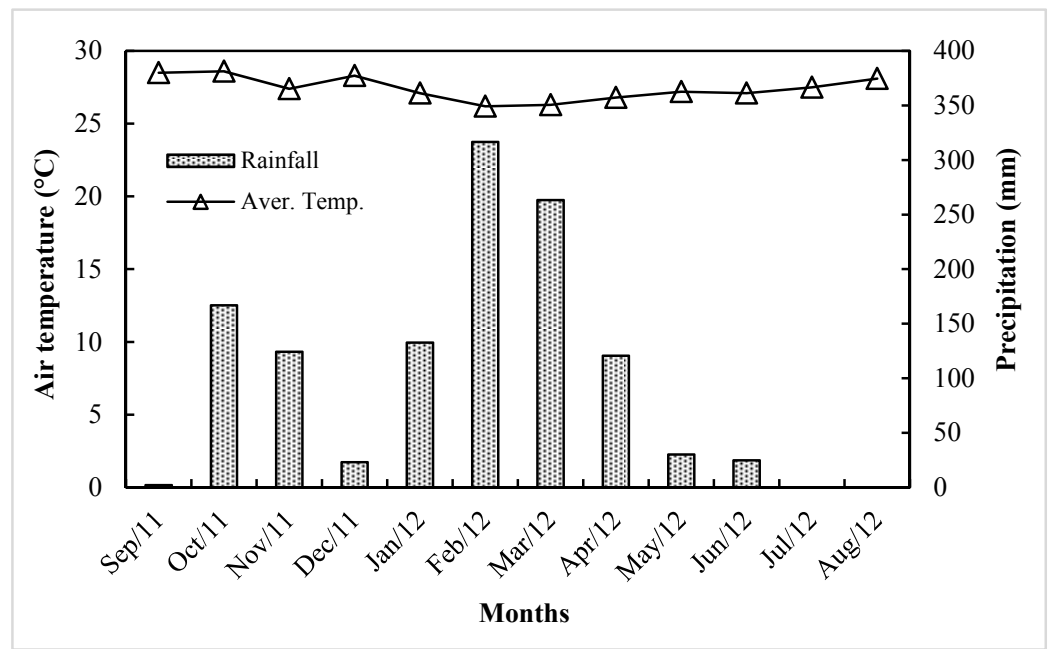

Figure 1. Monthly average temperatures and rainfall precipitation during the experimental period. Data obtained from a meteorological station adjacent to the experimental area

A native Babaçu palm forest (Orbignya martiana) covered the experimental area until 1981. This is a typical plant species from transitional areas of Brazilian savannas and Amazon forest. After deforestation, a sugarcane crop was introduced and continuously cultivated until 2009. The conventional soil tillage was adopted, and the harvest of sugarcane was performed always after burning. During this period, the crop was re-planted every five-year period after plowing the soil with a disc plough, followed by one pass of a disk harrow and then a soil furrow. Sugarcane stalks were planted in $40 \mathrm{~cm}$-deep soil furrows. In each planting operation, the soil was fertilized with 25,150 and $75 \mathrm{~kg} \mathrm{ha}^{-1}$ of $\mathrm{N}$ (as urea), $\mathrm{P}_{2} \mathrm{O}_{5}$ (as single superphosphate) and $\mathrm{K}_{2} \mathrm{O}$ (as potassium chloride), respectively, and $500 \mathrm{~kg} \mathrm{ha}^{-1}$ of dolomitic lime. Annually, the soil was fertilized with additional $40 \mathrm{~kg}$ ha ${ }^{-1}$ of $\mathrm{N}$ as ammonium sulfate $\left[\mathrm{SO}_{4}\left(\mathrm{NH}_{4}\right)_{2}\right]$. 


\subsection{Field Experiment}

The experiment started in September 2010 in a first ratoon area and was repeated in September 2011 in a second ratoon area (cultivar SP813250) with $1.4 \mathrm{~m}$ of inter-row spacing. In both years, after the manual harvesting of stalks, the remaining straw (leaves and tops) was removed from the area, weighed and re-distributed to the plots (10 m width $\times 15 \mathrm{~m}$ length) according to the different treatments. The field experiment was set in completely randomized design, comprising five treatments and four replicates; the five straw rates were applied and maintained on the soil surface $\left(\mathrm{T} 1=0 \mathrm{Mg} \mathrm{ha}^{-1} ; \mathrm{T} 2=2.2 \mathrm{Mgha}^{-1} ; \mathrm{T} 3=5.1 \mathrm{Mg} \mathrm{ha}^{-1} ; \mathrm{T} 4=7.8 \mathrm{Mg} \mathrm{ha}^{-1}\right.$ and; $\mathrm{T} 5=$ $12.0 \mathrm{Mg} \mathrm{ha}^{-1}$ ).

\subsection{Soil Sampling and Analysis}

Soil samples were collected in August 2010, prior to the experiment installation, in order to allow the preliminary evaluation of soil chemical and physical properties. For this study, detailed soil samplings were performed in February 2012, during the rainy season, and in August 2012, after sugarcane harvesting. During the soil sampling, three mini-trenches were opened in each experimental plot and soil subsamples were collected at $0-0.05,0.05-0.10,0.10-0.20$ and $0.20-0.40 \mathrm{~cm}$ depths, and bulked to form form composite samples. Samples were transported to the laboratory in cooled boxes, passed through a $2.0 \mathrm{~mm}$ sieve and separated into two aliquots of $300 \mathrm{~g}$. One aliquot of each sample was placed in plastic bags and immediately stored at $4{ }^{\circ} \mathrm{C}$ for further microbial analyses. The other aliquot was air-dried and stored at room temperature prior to chemical analyses. Metal rings $\left(49.06 \mathrm{~cm}^{3}\right)$ were used to collect intact soil cores using an Uhland auger, in order to determine soil bulk density in all treatments.

Soil samples were passed through a $0.21 \mathrm{~mm}$ sieve for chemical analysis. Soil organic carbon content was measured by wet digestion with a mixture of potassium dichromate and sulfuric acid under heating (Yeomans \& Bremmer, 1988). Soil organic carbon stocks for each soil layer were calculated using the equation: SOC stock $=$ SOC content $\times$ Ds $\times e$; where SOC stock is the total organic carbon pool $\left(\mathrm{Mg} \mathrm{ha}^{-1}\right)$ in each soil layer, SOC content is the organic carbon $\left(\mathrm{g} \mathrm{kg}^{-1}\right)$ in a given soil depth, Ds is the soil bulk density and " $e$ " is the thickness of the soil layer at each depth. The dissolved organic carbon (DOC) was quantified according to Scaglia and Adani (2009). The characterization of soil organic matter pools was given by the extraction and determination of fulvic acids (FAF), humic acids (HAF) and humin (HUM), which were performed with the combination of the methods proposed by Kononova (1982), and Swift (1996). The quantification of the carbon in the extracts of each fraction was carried out by carbon oxidation with potassium dichromate and titration of the excess. The alkaline extract $(\mathrm{AE}=\mathrm{FAF}+\mathrm{HAF})$, the $\mathrm{HAF} / \mathrm{FAF}$ ratio, and the AE/HUM ratio were calculated according to Benites et al. (2003). The humification index (HI) (Canellas \& Santos, 2005) was calculated using the equation: HI (\%) = $(\mathrm{HAF}+\mathrm{HUM}+\mathrm{FAF}) / \mathrm{SOC}$ content $\times 100$, where HAF is the humic acid, HUM the humin, FAF the fulvic acid and SOC the soil organic carbon content. This index allows estimating the proportion of humified organic matter relative to the total soil organic carbon content.

The soil microbial carbon $\left(\mathrm{C}_{\mathrm{MIC}}\right)$ was determined by the irradiation-extraction method (Ferreira, 1999). The basal respiration was determined by quantification of $\mathrm{C}_{-} \mathrm{CO}_{2}$ produced by incubated soil samples, according to Alef and Nannipieri (1995). The metabolic quotient $\left(q \mathrm{CO}_{2}\right)$ was calculated as the ratio of basal respiration to $\mathrm{C}_{\mathrm{MIC}}$ (Anderson and Domsch 1985). The microbial quotient $\left(q_{\mathrm{MIC}}\right)$, which is a measure of carbon availability, was calculated by the ratio between $\mathrm{C}_{\text {MIC }}$ and TOC (Sparling, 1992).

\subsection{Statistical Analysis}

All statistical analyses were performed using SAS 9.2 (SAS, 2003) at $\alpha<0.05$. The data were checked for normality and homogeneity of variances and transformed to $\log (\mathrm{x})+2$ when necessary to meet the assumptions of ANOVA. Transformations were performed for data regarding fulvic acids $(0-0.05 \mathrm{~m})$, alkaline extract $(0-0.05 \mathrm{~m})$ and microbial quotient $(0.20-0.40 \mathrm{~m})$. Regression curves were fit to the data based on the rates of sugarcane straw maintained on the soil. Data without transformations are displayed in all the figures.

\section{Results and Discussion}

\subsection{Results}

\subsubsection{SOC Stocks}

Sugarcane straw significantly influenced the SOC stocks in both rainy and dry seasons (Table 1; Figures 2a and 2b). Except for the 0-0.05 m soil layer in the rainy season, linear models were fit to the data. In the rainy season, the SOC pools were similar at 0-0.05, 0.05-0.10 and 0.10-0.20 m depths with the amendment of $12 \mathrm{Mg} \mathrm{ha} \mathrm{g}^{-1}$ of sugarcane straw. However, in the dry season, higher SOC stocks were observed in the top soil compared to 
deeper soil layers. For the $0-0.05$ and $0.05-0.10 \mathrm{~m}$ layers, there was a significant increase in the SOC stock from the first to the second sampling period.

Table 1. ANOVA outputs (P-values) for soil organic carbon stocks (SOC), dissolved organic carbon (DOC), labile carbon $\left(\mathrm{C}_{\mathrm{LABIL}}\right)$, fulvic acids $(\mathrm{FAF})$, humic acids (HAF), alkaline extract (AE), alkaline extract/HAF ratio (AE/HAF), humins (HUM), humification index $(\mathrm{HI})$, microbial carbon $\left(\mathrm{C}_{\mathrm{MIC}}\right)$, basal respiration, microbial quotient $(q \mathrm{MIC})$ and metabolic quotient $\left(q \mathrm{CO}_{2}\right)$ in the rainy and dry seasons

\begin{tabular}{|c|c|c|c|c|c|c|c|c|}
\hline \multirow{3}{*}{ Response variables } & \multicolumn{8}{|c|}{ Source of variation } \\
\hline & \multicolumn{4}{|c|}{ Soil depths, m (rainy season) } & \multicolumn{4}{|c|}{ Soil depths, m (dry season) } \\
\hline & $0-0.05$ & $0.05-0.10$ & $0.10-0.20$ & $0.20-0.40$ & $0-0.05$ & $0.05-0.10$ & $0.10-0.20$ & $0.20-0.40$ \\
\hline SOC & 0.019 & 0.0004 & 0.002 & 0.0006 & 0.016 & 0.008 & 0.001 & 0.015 \\
\hline DOC & n.s. & n.s. & 0.002 & 0.003 & - & - & - & - \\
\hline $\mathrm{C}_{\text {LABIL }}$ & n.s. & 0.005 & n.s. & n.s. & - & - & - & - \\
\hline FAF & $0.049 *$ & 0.041 & n.s. & n.s. & - & - & - & - \\
\hline HAF & 0.045 & 0.026 & 0.014 & n.s. & - & - & - & - \\
\hline $\mathrm{AE}$ & $0.043^{*}$ & 0.020 & n.s. & n.s. & - & - & - & - \\
\hline $\mathrm{AE} / \mathrm{HAF}$ & n.s. & 0.049 & n.s. & n.s. & - & - & - & - \\
\hline HUM & 0.009 & 0.008 & 0.005 & 0.016 & - & - & - & - \\
\hline HI & 0.009 & n.s. & n.s. & n.s. & - & - & - & - \\
\hline $\mathrm{C}_{\mathrm{MIC}}$ & $<0.0001$ & $<0.0001$ & 0.012 & 0.003 & $<0.0001$ & 0.014 & n.s. & n.s. \\
\hline Basal resp. & 0.0005 & 0.007 & 0.002 & 0.0002 & 0.023 & 0.0003 & n.s. & 0.012 \\
\hline$q_{\mathrm{MIC}}$ & 0.019 & $<0.0001$ & n.s. & n.s. & n.s. & 0.050 & 0.015 & $0.029^{*}$ \\
\hline$q_{\mathrm{CO} 2}$ & 0.022 & n.s. & n.s. & n.s. & n.s. & n.s. & n.s. & n.s. \\
\hline
\end{tabular}

Note. Levels of significance are given when $\mathrm{P} \leq 0.05$; otherwise results are stated as 'not significant' (n.s.).

* Original data transformed to $\log (\mathrm{x})+2$.

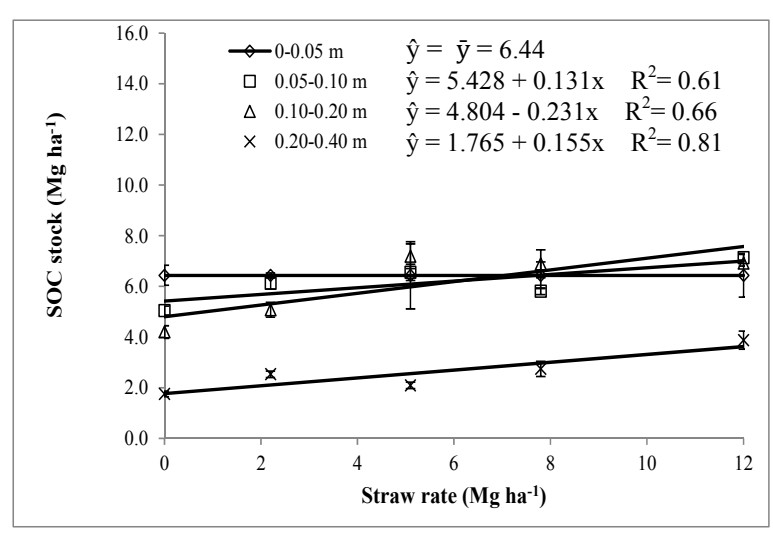

a

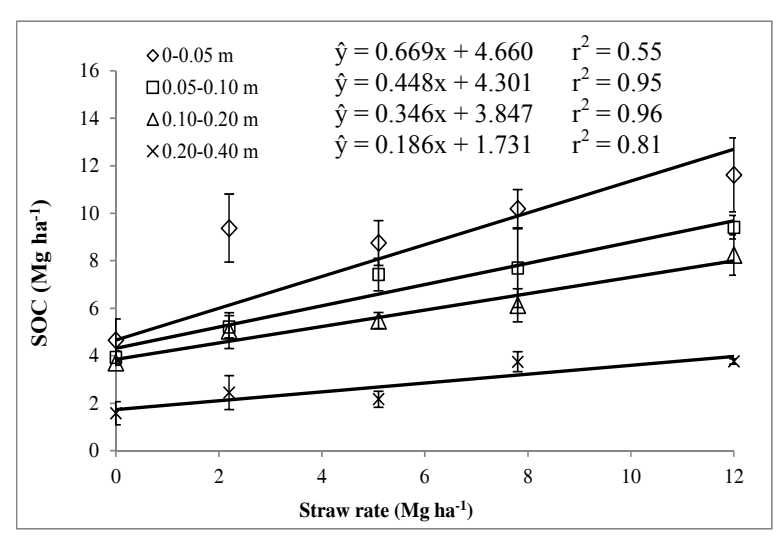

b

Figure 2. Soil organic carbon $\left(\mathrm{Mg} \mathrm{ha}^{-1}\right)$ at different soil layers of a Plinthosol, with different sugarcane straw rates deposited on the soil surface. Data from samples collected in the rainy (a) and dry (a) seasons

DOC rates were measured in only the rainy season, and they were influenced by the rate of sugarcane straw at the bottom soil layers $(0.10-0.20$ and $0.20-0.40 \mathrm{~m})$, but no significant effects of the treatments were observed in the top soil layers $(0-0.05$ or $0.05-0.10 \mathrm{~m})$, as indicated in Figure 3. There was a quadratic increase in the DOC rates with increasing amounts of straw. 


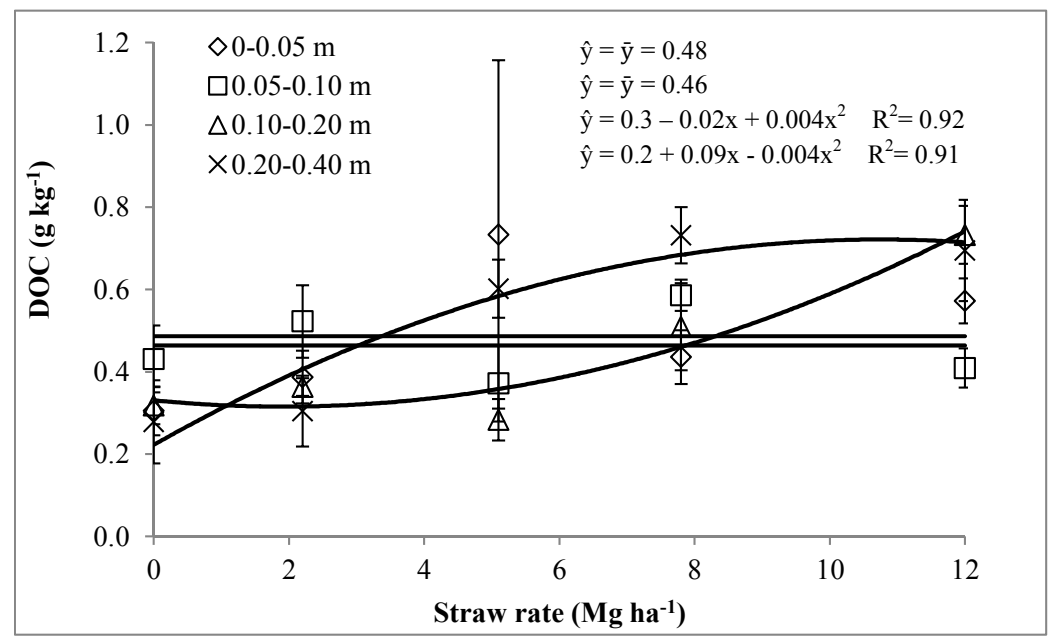

Figure 3. Dissolved organic carbon $\left(\mathrm{g} \mathrm{kg}^{-1}\right)$ at different soil layers of a Plinthosol, with different sugarcane straw rates deposited on the soil surface. Data from samples collected in the rainy season

\subsubsection{Chemical Attributes}

The sugarcane straw influenced the FAF content in the top soil in the rainy season (Figure 4a). At $0-0.05$ and $0.05-0.10 \mathrm{~m}$ depths, the values ranged linearly from 0.7 to $2.4 \mathrm{~g} \mathrm{~kg}^{-1}$ and from 0.8 to $1.4 \mathrm{~g} \mathrm{~kg}^{-1}$, respectively. However, FAF content at 0.10-0.20 and 0.20-0.40 m was not influenced by the sugarcane straw. HAF content was significantly affected by the rate of sugarcane straw in the rainy season except at the $0.20-0.40 \mathrm{~m}$ depth (Figure $4 \mathrm{~b}$ ). In general, HAF increased with straw rate, demonstrating a quadratic response. Similar values across different soil depths were observed at $12 \mathrm{Mg} \mathrm{ha}^{-1}$ of straw, with a trend of stabilization in the HAF content beyond this rate.

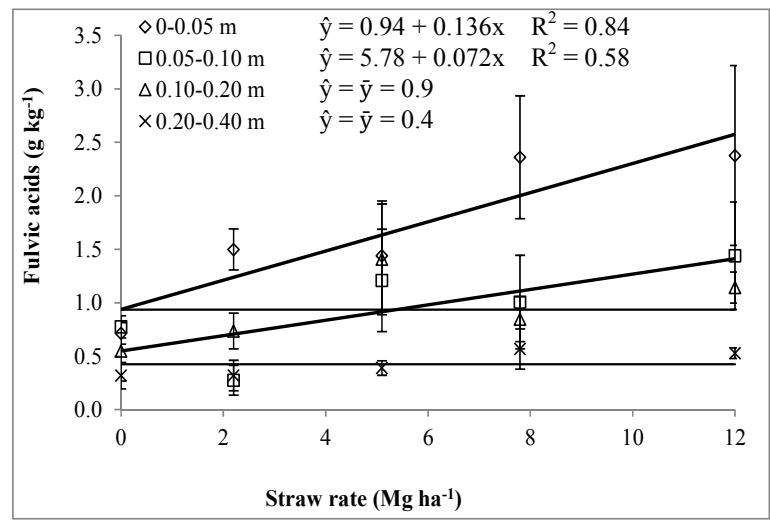

a

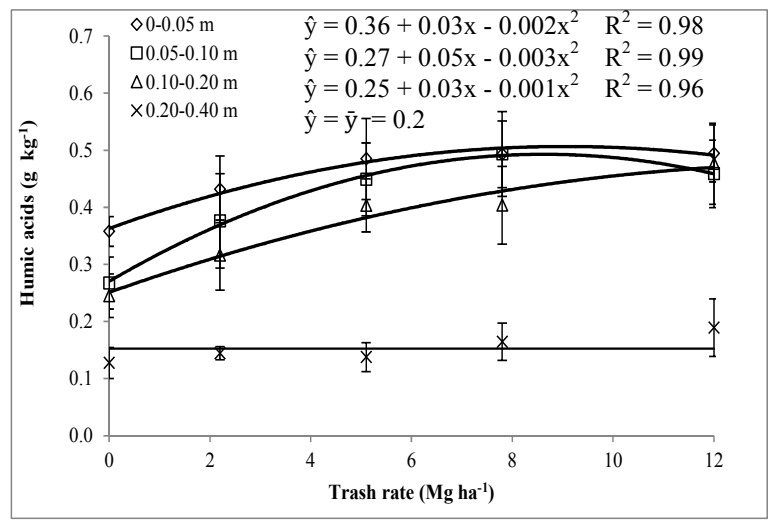

b

Figure 4. Fulvic (a) and humic (b) acids contents $\left(\mathrm{g} \mathrm{kg}^{-1}\right)$ at different soil layers of a Plinthosol, with different sugarcane straw rates deposited on the soil surface. Data from samples collected in the rainy season

The straw rate significantly increased the alkaline extract at $0-0.05$ and $0.05-0.10 \mathrm{~m}$ depths (Figure $5 \mathrm{a}$ ). The values fit to a quadratic curve at $0-0.05 \mathrm{~m}$ and to a linear curve at $0.05-0.10 \mathrm{~m}$, with values of 2.9 and $1.9 \mathrm{~g} \mathrm{~kg}^{-1}$, respectively, at the rate of $12 \mathrm{Mg} \mathrm{ha}^{-1}$ of sugarcane straw. On the other hand, AE/HUM was only significantly affected by the straw rate at the 0.05-0.10 m layer (Figure 5b). 


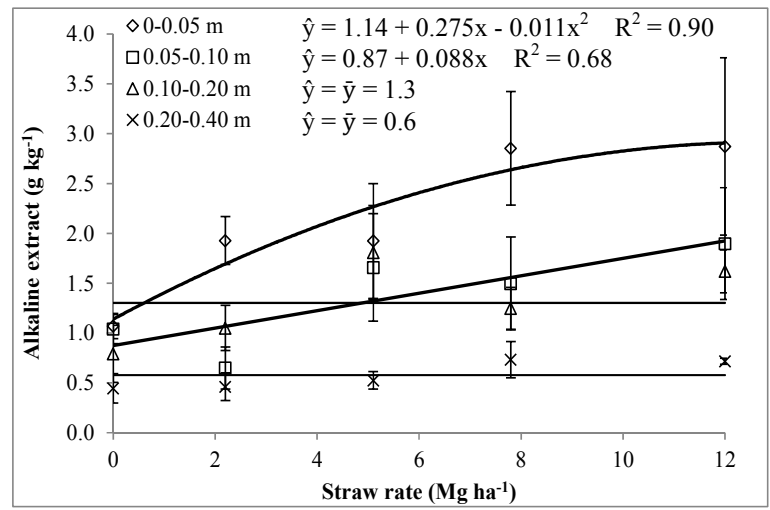

a

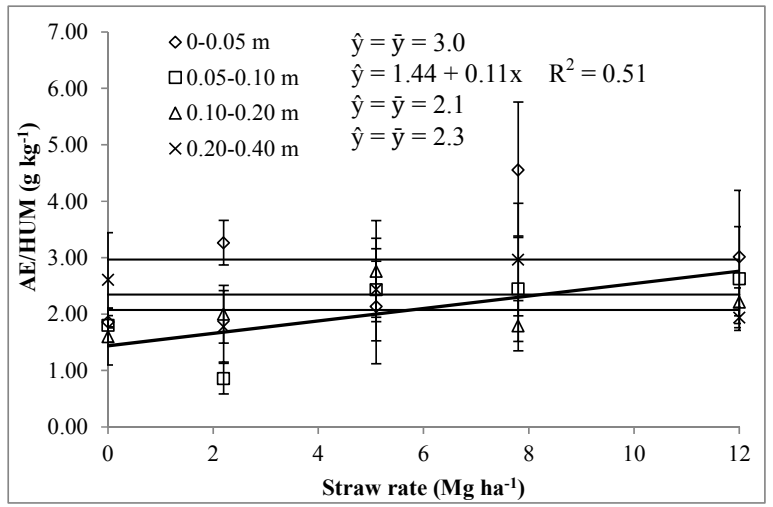

b

Figure 5. Alkaline extract (a) and alkaline extract/humic acid ratio (b) contents ( $\left.\mathrm{g} \mathrm{kg}^{-1}\right)$ at different soil layers of a Plinthosol, with different sugarcane straw rates deposited on the soil surface. Data from samples collected in the rainy season

The straw rate significantly increased HUM content at all soil depths during the rainy season (Figure 6a). However, only at the bottom soil layers $(0.10-0.20$ and $0.20-0.40 \mathrm{~m})$ was it possible to fit polynomial models to the data. HUM content was lower at the bottom soil compared to the top soil, but with high sugarcane straw rates, the values found at $0.10-0.20 \mathrm{~m}$ were similar to those at $0.05-0.10 \mathrm{~m}$. Although adjusted to a crescent linear model, the values in the bottom soil remained lower than those observed in the top soil. The treatments significantly influenced the humification index at the $0-0.05 \mathrm{~m}$ soil depth (Figure 6b). This index decreased significantly in the rainy season as more sugarcane crop residue was maintained on the soil.

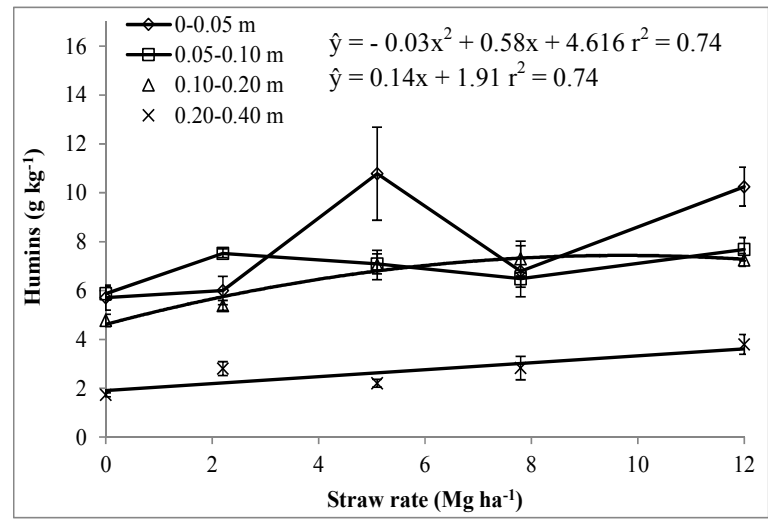

a

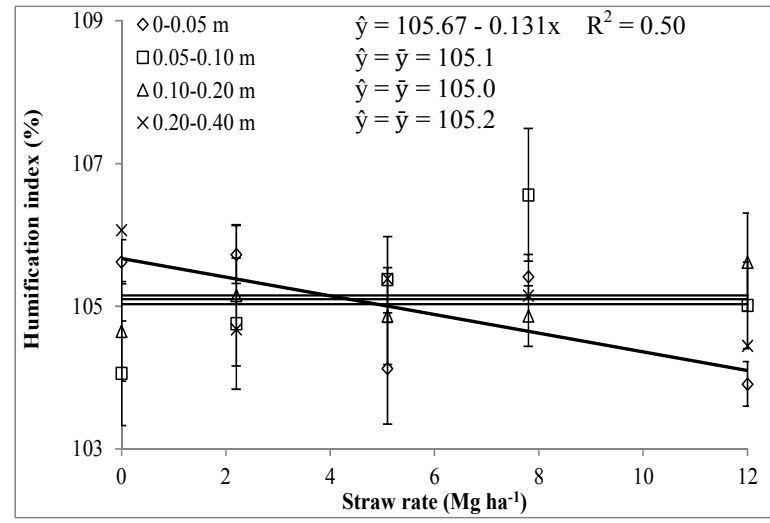

b

Figure 6. Humins (a) content $\left(\mathrm{g} \mathrm{kg}^{-1}\right)$ and humification index (b) at different soil layers of a Plinthosol, with different sugarcane straw rates deposited on the soil surface. Data from samples collected in the rainy season

\subsubsection{Biological Attributes}

In the rainy season, soil microbial $\mathrm{C}$ increased significantly as a response to the straw rate at all evaluated soil depths (Figure 7a). However, a more pronounced increase in the $\mathrm{C}_{\text {MIC }}$ was found at the $0-0.05 \mathrm{~m}$ layer where a quadratic model was adjusted to the data. For the other soil layers, linear models were adjusted. Moreover, at the 0-5 m depth the values of $\mathrm{C}_{\text {MIC }}$ were higher than at $0.05-0.10 \mathrm{~m}, 0.10-0.20 \mathrm{~m}$ and $0.20-0.40 \mathrm{~m}$. In the dry season, only at $0-0.05$ and $0.05-0.10 \mathrm{~m}$ depths significant effects of the straw rate on $\mathrm{C}_{\mathrm{MIC}}$ were observed (Figure $7 \mathrm{~b}$ ). For both soil layers, a quadratic trend was adjusted to the data, but differently from the rainy season, there was a tendency toward stabilization with high rates of sugarcane straw. 


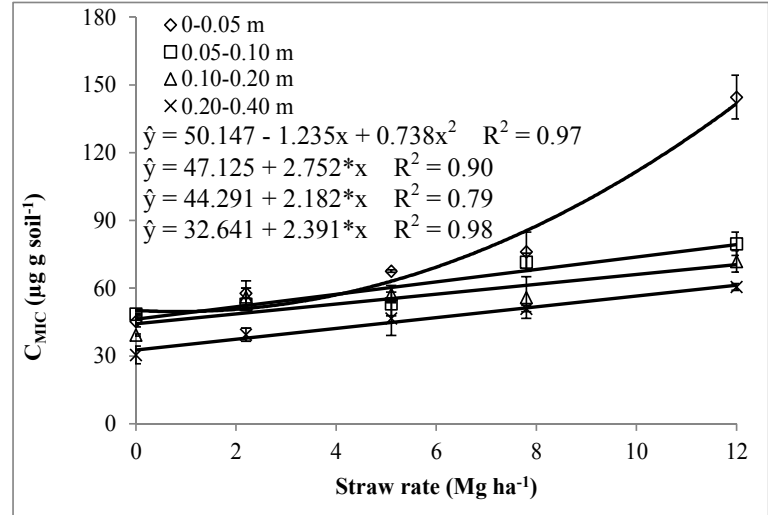

a

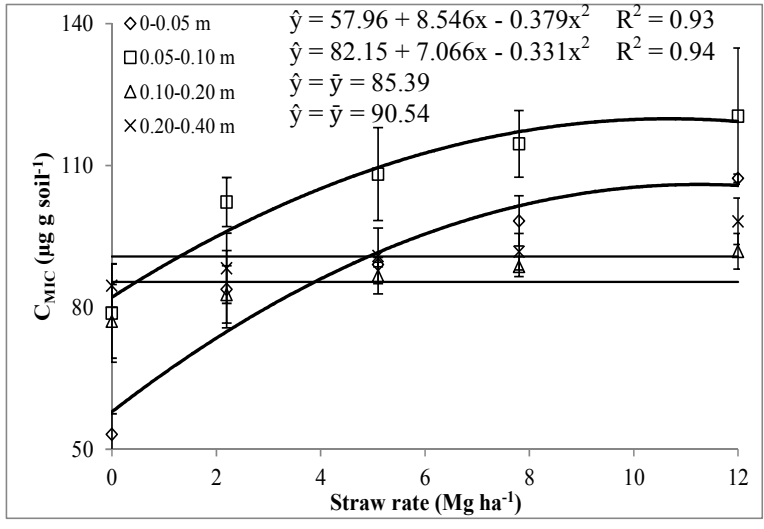

b

Figure 7. Microbial carbon ( $\mu \mathrm{g} \mathrm{C} \mathrm{g}{ }^{-1}$ soil) at different soil layers of a Plinthosol, with different sugarcane straw rates deposited on the soil surface. Data from samples collected in the rainy (a) and dry (b) seasons

Basal respiration in the rainy season increased after the addition of sugarcane straw in all soil depths (Figure 8a). In the top soil, linear models were fitted to the data with values ranging from 20.83 to $35.85 \mu \mathrm{g} \mathrm{CO}_{2} \mathrm{~g} \mathrm{soil}^{-1} \mathrm{day}^{-1}$ $(0-0.05 \mathrm{~m})$ and from 21.21 to $33.87 \mu \mathrm{g} \mathrm{CO}_{2} \mathrm{~g}$ soil $^{-1}$ day $^{-1}(0.05-0.10 \mathrm{~m})$. In the bottom soil, the data presented a quadratic trend. A similar increase in $\mathrm{CO}_{2}$ emissions with increasing rates of sugarcane straw was observed in the dry season except for the lack of significance at the $0.10-0.20 \mathrm{~m}$ soil layer (Figure $8 \mathrm{~b}$ ). The amount of $\mathrm{CO}_{2}$ released by the $0-0.05$ and $0.05-0.10 \mathrm{~m}$ layers in the dry season was higher than that observed in the same soil layers in the rainy season. At $0.10-0.20$ and $0.20-0.40 \mathrm{~m}$, the amounts of $\mathrm{CO}_{2}$ released were close to those observed in the rainy season.

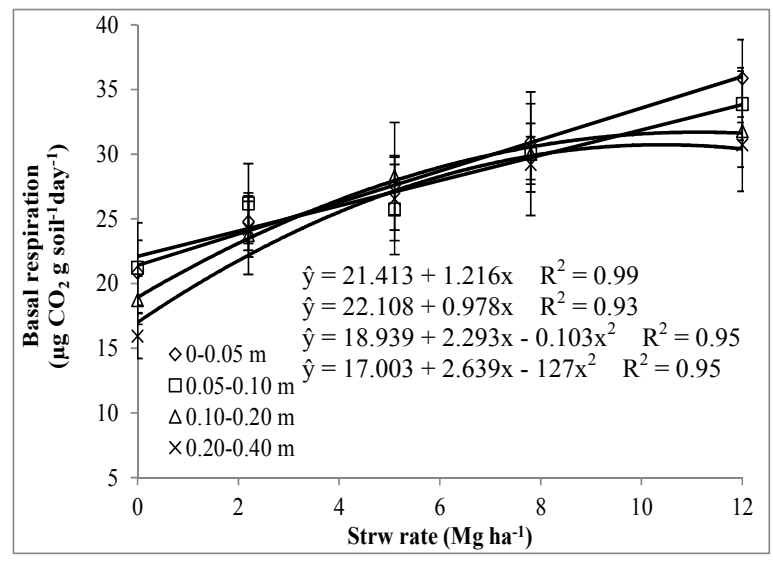

$\mathbf{a}$

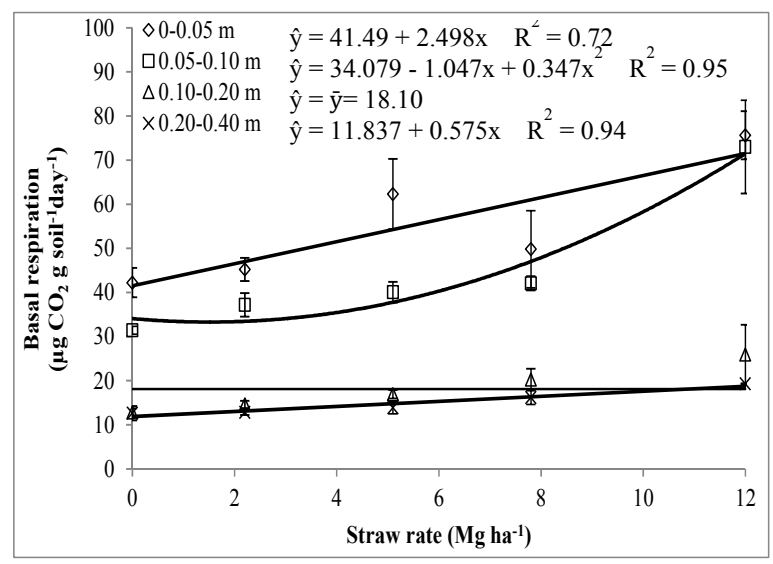

b

Figure 8. Basal respiration ( $\mu \mathrm{g} \mathrm{C}-\mathrm{CO}_{2} \mathrm{~g}$ soil $^{-1}$ day $^{-1}$ ) at different soil layers of a Plinthosol, with different sugarcane straw rates deposited on the soil surface. Data from samples collected in the rainy (a) and dry (b) seasons

Microbial quotient expresses the percentage of $\mathrm{C}$ present in microbial biomass in relation to TOC. During the rainy season, a significant linear increase in $q_{\mathrm{MIC}}$ was evident at 0-0.05 and 0.05-0.10 $\mathrm{m}$ depths (Figure 9a). There was no significant effect at $0.10-0.20$ or $0.20-0.40 \mathrm{~m}$. Conversely, in the dry season, $q_{\text {MIC }}$ tended to decrease with increasing amounts of sugarcane crop residue maintained on the soil surface (Figure 9b). The effects were only significant at $0.05-0.10,0.10-0.20$ and $0.20-0.40 \mathrm{~m}$ depths. No significant effect was found at the $0-0.05 \mathrm{~m}$ depth for the different straw rates. The $q_{\mathrm{MIC}}$ values were higher in the dry season and ranged from 3.5 to close to 2.1 in the $0-0.05$ m layer. 


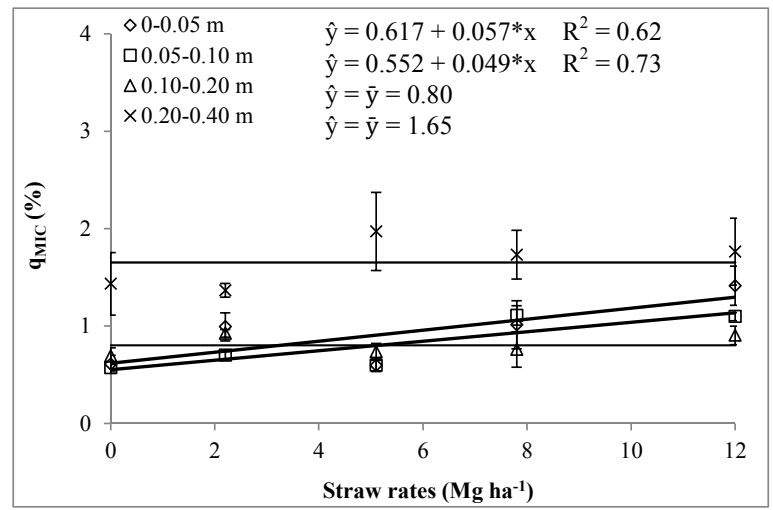

a

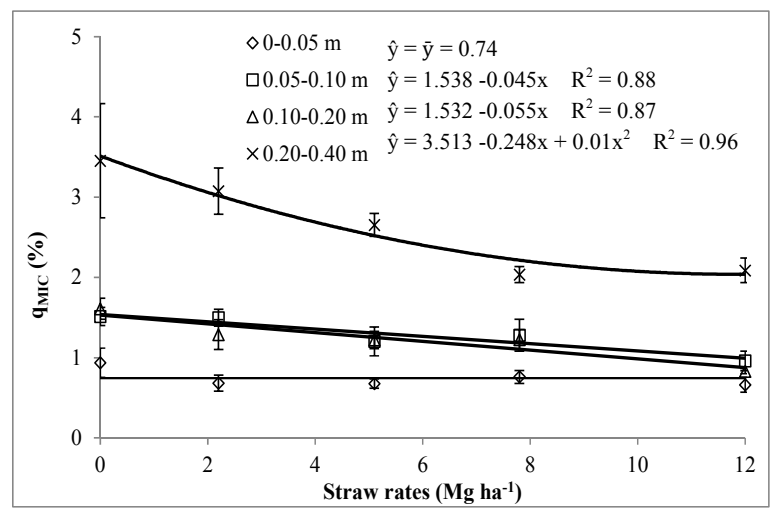

b

Figure 9. Microbial quotient (\%) at different soil layers of a Plinthosol, with different sugarcane straw rates deposited on the soil surface. Data from samples collected in the rainy (a) and dry (b) seasons

Although sugarcane straw on the soil surface increased the basal respiration in the rainy season, the amount of $\mathrm{CO}_{2}$ released per unit of microbial $\mathrm{C}\left(q \mathrm{CO}_{2}\right)$ was significantly reduced at the $0-0.05 \mathrm{~m}$ soil depth (Figure 10). A quadratic model was adjusted to the data, which varied from 0.46 (control) to $0.25 \mu \mathrm{g} \mathrm{C}-\mathrm{CO}_{2} \mathrm{mg} \mathrm{C}_{\mathrm{MIC}}{ }^{-1} \mathrm{day}^{-1}$ for the highest rate of sugarcane straw. There were no significant effects of the treatments in the other soil depths. In the dry season, no significant effects of the treatments were observed in either the top soil or the deeper soil.

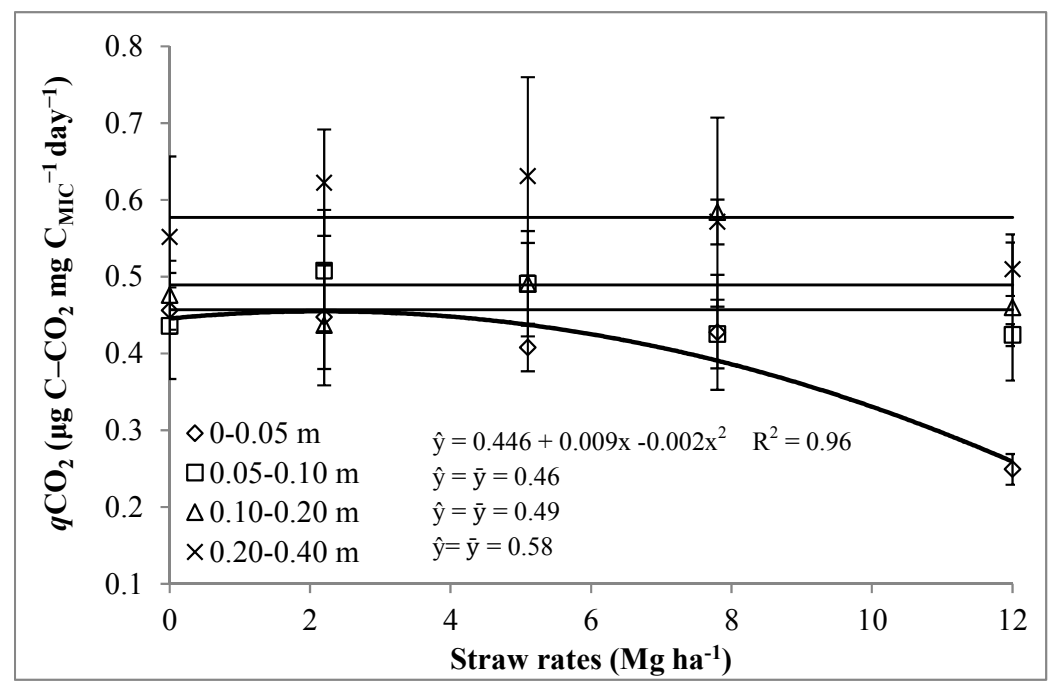

Figure 10. Metabolic quotient ( $\mu \mathrm{g} \mathrm{C}-\mathrm{CO}_{2} \mathrm{mg} \mathrm{C}_{\mathrm{MIC}^{-1}}$ day $^{-1}$ ) at different soil layers of a Plinthosol, with different sugarcane straw rates deposited on the soil surface. Data from samples collected in the rainy season

\subsection{Discussion}

\subsubsection{SOC and Stocks}

Our results consistently showed that sugarcane straw increases SOC stocks, confirming previous studies that showed the restoration of SOM with the maintenance of crop residues on the soil (Bordonal et al., 2013; Cerri et al., 2011; Correia \& Aleoni, 2011; Razafimbelo et al., 2006; Souza et al., 2012; Sparling, 1992; Thorburn et al., 2001). Our research evidenced the short-term effects of green sugarcane harvesting on the increase of SOC even in the bottom soil, although more pronounced increases occurred in the top soil where the straw mulch was formed. 
Before this experiment, the area under study remained under sugarcane cultivation with pre-harvest burning for 27 years, and crop renovations were conducted with conventional soil tillage. These practices contributed to accelerated SOM decomposition (Cherubin et al., 2015). Therefore, the short-term increase in SOC in our study may have recovered only a fraction of the $\mathrm{C}$ lost during almost three decades of intense cultivation and little input of organic residue. It is likely that further increases in SOC stocks would be observed if the experiment was maintained for periods longer than that considered in this study.

The significant increases in the DOC in the bottom soil may have been a consequence of intense rain events that leached part of this $\mathrm{C}$ pool to deep soil layers where it accumulated. This process may also explain the changes in $\mathrm{C}_{\mathrm{MIC}}$ found between the two seasons. The migration of DOC to deep soil layers in the rainy season provided an energy source for microorganisms, resulting in increased soil microbial biomass. Moreover, the vertical migration of soluble C fractions leads to increases in SOC (Correia \& Alleoni, 2011), which would explain the short-term increases of SOC at the bottom soil layers assessed in this study. According to Razafimbelo et al. (2006), water soluble $\mathrm{C}$ in areas under green sugarcane management is responsible for up to $10 \%$ of total SOC.

\subsubsection{Chemical Attributes}

Sugarcane straw increased the fulvic (FAF) and humic acids (HAF) fractions, which is in line with the data presented by Canellas et al. $(2003,2007)$. However, Canellas et al. (2003) reported great increases in HAF to the $0.40 \mathrm{~m}$ soil layer (486\%), whereas in our experiment the effects were evident to only the $0.20 \mathrm{~m}$ soil layer. These authors also stated that although representing a small fraction of the total SOC, HAF is mobile and can migrate to deep soil layers.

High rates of sugarcane straw increased the humin fraction in all soil layers despite the short-term nature of this study. Humins represent the most stable humified SOC pool in soil (Canellas et al., 2003), being recalcitrant to microbial action (Canellas et al., 2007). Razafimbelo et al. (2006) reported the highest amounts of SOC in fine fractions found in areas with green sugarcane harvesting. The authors emphasized that the mean residence time of carbon associated with fine soil fractions could amount to 40 years, whereas it can be less than 5 years for carbon associated with coarse soil fractions.

Similarly, Thorburn et al. (2012) reported the highest amounts of non-labile C, particularly close to the soil surface when sugarcane straw was maintained on the soil surface. However, the extent of these changes is site-dependent. Increases in SOC and in more condensed humified SOC fractions in the areas of green cane harvesting are concomitant with increases in the degree of aromaticity, suggesting important changes in the SOM humification process (Canellas et al., 2007). The presence of aromatic structures allows inferences regarding the degree of SOM humification and its stability (Dick et al., 2005).

The increase in alkaline extract in the top soil is consistent with concomitant increases in humic and, particularly, fulvic acids. This shows an increase in the absolute amount of $\mathrm{C}$ being incorporated into humified fractions and thus into relatively stable SOC pools, which is in agreement with the observations of Canellas et al. (2003) in areas with green cane harvesting. Moreover, the proportion of $\mathrm{AE}$ extract in relation to the humin fraction indicates the amount of this humified $\mathrm{C}$ that is incorporated into the most stable SOC forms.

Data of this study evidenced an increase in the AE/HUM ratio in the $0.05-0.10 \mathrm{~m}$ soil layer. In spite of this, a decreasing humification index was observed in the $0-0.05 \mathrm{~m}$ soil layer with increasing straw rates. This suggests that although a great amount (in absolute terms) of $\mathrm{C}$ was incorporated into humified fractions, its proportion in relation to labile SOC fractions was reduced in the top soil. Similarly, Thorburn et al. (2012) found the greatest amount of labile SOC in top soil layers when sugarcane residue was retained on the soil surface, suggesting that sugarcane straw adds great amounts of labile $\mathrm{C}$ to the soil.

On the other hand, Panosso et al. (2011) found the greatest humification index in areas under green cane harvest, suggesting that this would lead to increases in SOM stocks. High proportions of C in labile pools would result in higher decomposition rates, as more $\mathrm{C}$ would be available for microbial attack (Souza et al., 2012).

Although the great amount of straw input in our study resulted in proportionally more labile $\mathrm{C}$ added to the soil, it also contributed to increases in the absolute amount of the humified $\mathrm{C}$ fraction, which was determinant for increases in the recalcitrant $\mathrm{C}$ pools and SOC stocks. Moreover, sugarcane residue decomposes more slowly than other crop residues with similar characteristics (Thorburn et al., 2001), which may have further contributed to the increased SOC stocks.

\subsubsection{Biological Attributes}

High microbial activity, particularly in the top soil, is a result of favorable environmental conditions, e.g., high temperature, water availability (Araújo et al., 2013), and substrate availability provided by sugarcane straw 
(Souza et al., 2012). The high values of $\mathrm{CO}_{2}$ found in the dry season suggest that the straw maintained on the soil surface also conserved soil moisture at levels suitable for microbial biomass, thereby favoring microbial activity. In addition, the high $\mathrm{C}$ stocks found in the dry season provided a source of energy allowing high microbial activity when soil moisture was not a limiting factor.

Differences in $q_{\mathrm{MIC}}$ between the rainy and dry seasons provide evidence that microbial biomass is more sensitive to short-term changes in environmental conditions than to the soil's chemical and physical properties (Souza et al., 2012). In the rainy season, data of this study indicated that proportionally more $C$ was immobilized as microbial biomass in the upper soil layers as more sugarcane straw was added to the soil. On the other hand, this trend seemed to assume an opposite direction in the dry season, indicating that a smaller proportion of total C was retained in the microbial biomass as the sugarcane straw rates increased on the soil surface.

This is consistent with values found by other authors under tropical environments (Souza et al., 2012) and suggests that the soil microbial population may be close to a steady state (Anderson \& Domsh, 1989). The data of this study also showed a decreased metabolic quotient $\left(q \mathrm{CO}_{2}\right)$ in the $0-0.05 \mathrm{~m}$ soil layer with increasing straw rates in the rainy season. This indicates a small proportion of $\mathrm{C}$ being released to the atmosphere as $\mathrm{CO}_{2}$ per unit of microbial C-biomass, thus suggesting high efficiency in the use of soil C. In the dry season, however, no changes were reported for different straw rates (data not shown), indicating that SOM may have reached some degree of stabilization (Mendonza et al., 2000).

\section{Conclusions}

The results from this study highlight the positive short-term effects of green sugarcane harvesting with the maintenance of straw on the soil surface on labile and humified SOC pools.

A decreased humification index in the most superficial soil layer suggests that proportionally more labile $\mathrm{C}$ fractions were made available in the soil, consequently resulting in pronounced microbial activity.

However, some microbial indicators point towards a steady equilibrium in SOC turnover, which can lead to future lower increases in SOC stocks if high straw amounts are maintained on the soil surface.

This suggests that for subsequent cropping seasons, part of the sugarcane straw could be removed from the field and used for other purposes.

\section{References}

Alef, K., \& Nannipieri, P. (1995). Methods in applied soil microbiology and biochemistry. London, Academic Press.

Anderson, J. P. E., \& Domsch, K. H. (1985). Determination of ecophysiological maintenance carbon requirements of soil microorganisms in dormant state. Biology and Fertility of Soils, 1, 81-89. https://doi.org/10.1007/BF00255134

Anderson, T. H., \& Domsh, K. H. (1989). Ratios of microbial biomass carbon to total organic carbon in arable soils. Soil Biology and Biochemistry, 21, 471-79. https://doi.org/10.1016/0038-0717(89)90117-X

Araújo, A. S. F., Cesarz, S., Leite, L. F. C., Borges, C. D., Tsai, S. M., \& Eisenhauer, N. (2013). Soil microbial properties and temporal stability in degraded and restored lands of Northeast Brazil. Soil Biology Biochemestry, 66, 175-181. https://doi.org/10.1016/j.soilbio.2013.07.013

Benites, V. M., Madari, B., \& Machado, P. L. O. A. (2013). Extração e fracionamento quantitativo de substâncias húmicas do solo: um procedimento simplificado e de baixo custo. Brasília, Embrapa.

Bordonal, R. O., Figueiredo, E. B., Aguiar, D. A., Adami, M., Rudorff, B. F. T., \& La Scala, N. (2013). Greenhouse gas mitigation potential from green harvested sugarcane scenarios in São Paulo State, Brazil. Biomass Bioenergy, 59, 195-207. https://doi.org/10.1016/j.biombioe.2013.08.040

Canellas, L. C., \& Santos, G. A. (2005). Humosfera: Tratado preliminar sobre a química das substâncias húmicas. Campos dos Goytacazes.

Canellas, L. P., Baldotto, M. A., Busato, J. G., Marciano, C. R., Menezes, S. C., Silva, N. M., ... Martin-Neto, L. (2007). Estoque e qualidade da matéria orgânica de um solo cultivado com cana-de-açúcar por longo tempo. Revista Brasileira de Ciência do Solo, 31, 331-40. https://doi.org/10.1590/S0100-06832007000200015

Canellas, L. P., Velloso, A. C. X., Marciano, C. R., Ramalho, J. F. G. P., Rumjanek, V. M., Rezende, C. E., \& Santos, G. A. (2003). Propriedades químicas de um Cambissolo cultivado com cana-de-açúcar, com preservação do palhiço e adição de vinhaça por longo tempo. Revista Brasileira de Ciência do Solo, 27, 935-44. https://doi.org/10.1590/S0100-06832003000500018 
Cerri, C. C., Galdos, M. V., Maia, S. M. F., Bernoux, M., Feigl, B. J., Powlson, D., \& Cerri, C. E. P. (2011). Effect of sugarcane harvesting systems on soil carbon stocks in Brazil: an examination of existing data. European Journal of Soil Science, 62, 23-28. https://doi.org/10.1111/j.1365-2389.2010.01315.x

Cerri, C. C., Maia, S. M. F., Galdos, M. V., Cerri, C. E. P., Feigl, B. J., \& Bernoux, M. (2009). Brazilian greenhouse gas emissions: The importance of agriculture and livestock. Scientia Agricola, 66, 831-43. https://doi.org/10.1590/S0103-90162009000600017

Cherubin, M. R., Franco, A. L. C., Cerri, C. E. P., Oliveira, D. M. S., Davies, C. A., \& Cerri, C. C. (2011). Sugarcane expansion in Brazilian tropical soils-Effects of land use change on soil chemical attributes. Agriculture, Ecosystems \& Environment, 211, 173-84. https://doi.org/10.1016/j.agee.2015.06.006

Correia, B. L., \& Alleoni, L. R. F. (2011). Conteúdo de carbono e atributos químicos de Latossolo sob cana-de-açúcar colhida com e sem queima. Pesquisa Agropecuária Brasileira, 46, 944-52. https://doi.org/ 10.1590/S0100-204X2011000800022

Dick, D. P., Gonçalves, C. N., Dalmolin, R. S. D., Knicker, H., Klamt, E., Kögel-Knabner, I., ... Martin-Neto, L. (2005). Characteristics of soil organic matter of different Brazilian Ferralsols under native vegetation as a function of soil depth. Geoderma, 124, 319-33. https://doi.org/10.1016/j.geoderma.2004.05.008

Ferreira, A. S. (1999). Utilização de microondas na avaliação da biomassa microbiana do solo. Revista Brasileira de Ciência do Solo, 23, 991-96. https://doi.org/10.1590/S0100-06831999000400026

IBGE. (2016). Sistema IBGE de recuperação automática. Levantamento Sistemático da Produção Agrícola. Retrieved from http://www.sidra.ibge.gov.br.

Kaschuk, G., Alberton, O., \& Hungria, M. (2011). Quantifying effects of different agricultural land uses on soil microbial biomass and activity in Brazilian biomes: Inferences to improve soil quality. Plant and Soil, 338, 467-81. https://doi.org/10.1007/s11104-010-0559-z

Kononova, M. M. (1982). Materia orgánica del suelo; su naturaleza, propiedades y métodos de investigación. Barcelona, Oikos-Tau.

Magalhães, P. S. G., Nogueira, L. A. H., Canatarella, H., Rossetto, R., Franco, H. C. J., \& Braunbeck, O. A. (2012). Agro-industrial technological paths. In M. K. Poppe, \& L. A. B. Cortez (Eds.), Sustainability of Sugarcane Bioenergy by Center of Strategic Studies and Management (CGEE) (pp. 27-69). Brasília, CGEE.

Mendonza, H. N. S., Lima, E., Anjo, L. H. C., Silva, L. A., Ceddia, M. B., \& Antunes, M. V. M. (2000). Propriedades químicas e biológicas de solo de tabuleiro cultivado com cana-de-açúcar com e sem queima da palhada. Revista Brasileira de Ciência do Solo, 24, 201-07. https://doi.org/10.1590/S0100-0683200 0000100022

Panosso, A. R., Marques, J. R. J., Milori, D. M. B. P., Ferraudo, A. S., Barbieri, D. M., Pereira, G. T., \& La Scala, J. R. N. (2011). Soil $\mathrm{CO}_{2}$ emission and its relation to soil properties in sugarcane areas under Slash-and-burn and Green harvest. Soil \& Tillage Research, 111, 190-96. https://doi.org/10.1016/ j.still.2010.10.002

Razafimbelo, T., Barthès, B., Larre-Larrouy, M. C., De Luca, E. F., Laurent, J. Y., Cerri, C. C., \& Feller, C. (2006). Effect of sugarcane residue management (mulching versus burning) on organic matter in a clayey Oxisol from southern Brazil. Agriculture, Ecosystems\& Environment, 115, 285-89. https://oi.org/10.1016/ j.agee.2005.12.014

SAS (Statistical Analysis System). (2003) SAS/STAT guide for personal computer (Version 9.1). Cary: SAS Institute.

Scaglia, B., \& Adani, F. (2009). Biodegradability of soil water soluble organic carbon extracted from seven different soils. Journal of Environmental Sciences, 21, 641-46. https://doi.org/10.1016/S1001-0742 (08)62319-0

Souza, R. A., Telles, T. S., Machado, W., Hungria, M., Tavares Filho, J., \& Guimarães, M. F. (2012). Effects of sugarcane harvesting with burning on the chemical and microbiological properties of the soil. Agriculture, Ecosystems \& Environment, 155, 1-6. https://doi.org/10.1016/j.agee.2012.03.012

Sparling, G. P. (1992). Ratio of microbial biomass carbon to soil organic carbon as a sensitive indicator of changes in soil organic matter. Australian Journal of Soil Research, 30, 195-207. https://doi.org/10.1071/ SR9920195 
Swift, R. S. (1996). Organic matter characterization. In D. L. Sparks (Ed.), Methods of soil analysis Part 3 (pp. 1011-20). Madison, America Society of Agronomy.

Thorburn, P. J., Meier, E. A., Collins, K., \& Robertson, F. A. (2012). Changes in soil carbon sequestration, fractionation and soil fertility in response to sugarcane residue retention are site-specific. Soil \& Tillage Research, 120, 99-111. https://doi.org/10.1016/j.still.2011.11.009

Thorburn, P. J., Probert, M. E., \& Robertson, F. A. (2001). Modeling decomposition of sugarcane surface residues with APSIM-residue. Field Crops Research, 70, 223-32. https://doi.org/10.1016/S0378-4290(01) 00141-1

Yeomans, J. C., \& Bremmer, J. M. (1998). A rapid and precise method for routine determination of organic carbon in soil. Communiction of Soil Science and Plant Analysis, 19, 1467-76. https://doi.org/10.1080/ 00103628809368027

\section{Copyrights}

Copyright for this article is retained by the author (s), with first publication rights granted to the journal.

This is an open-access article distributed under the terms and conditions of the Creative Commons Attribution license (http://creativecommons.org/licenses/by/4.0/). 